\title{
ABO and Rh (D) Blood Groups Among the Telugu Speaking Fishing Community of Andhra Pradesh
}

\author{
A. Papa Rao, K.K. Reddy and N.S. Balaji Rao
}

Anthropologists have used ABO and Rh blood group systems for the determination of frequencies of blood group alleles in human populations and with the help of these they have not only attempted the analysis of the history of populations but also used them to study the action of natural selection. Further, blood group systems are useful in determine the genetic variation within and between the populations. During the last four decades, numerous studies have been carried out on the genetic composition of various endogamous population groups in India (Bhasin et al., 1992;1994). However, genetic studies among fishing communities in India are very limited. Hence, in the present study the distribution of $\mathrm{ABO}$ and Rhesus blood groups has been reported among the Telugu speaking marine fishing community of coastal Andhra Pradesh.

\section{MATERIALS AND METHODS}

The blood samples were drawn from randomly selected 92 unrelated individuals of both the sexes from Kavali Revenue division of Nellore District, Andhra Pradesh.

\section{RESULTS AND DISCUSSION}

The frequency distribution of ABO phenotypes with gene frequencies are presented in table 1 . It is clear from the table that $O$ phenotype has the highest frequency $(45.65 \%)$ followed by $\mathrm{B}$ $(32.60 \%), \mathrm{A}(15.21 \%)$ and $\mathrm{AB}(6.52 \%)$. The overall picture of phenotypic frequencies of $\mathrm{ABO}$ blood groups is $\mathrm{O}>\mathrm{B}>\mathrm{A}>\mathrm{AB}$. The decreasing order of allele frequency in Fishermen is $O$

$\begin{aligned} & \text { Table 1: Percentage distribution } \\
& \text { and allele frequencies }\end{aligned}$
\begin{tabular}{lccc} 
Phenotypes & $\begin{array}{c}\text { Observed } \\
\text { number }\end{array}$ & $\%$ & $\begin{array}{c}\text { Allele } \\
\text { frequency }\end{array}$ \\
\hline $\mathrm{A}$ & 14 & 15.21 & $A=0.1155$ \\
$\mathrm{~B}$ & 30 & 32.60 & $B=0.2199$ \\
$\mathrm{O}$ & 42 & 45.65 & $O=0.6756$ \\
$\mathrm{AB}$ & 6 & 6.52 & \\
\hline Total & 92 & 100.00 & $A+B+O=1.000$ \\
\hline $\mathrm{D} / \sigma=1.130$ & & &
\end{tabular}

Table 2: Percentage distribution of $\mathrm{Rh}(\mathrm{D})$ phenotypes and allele frequencies

\begin{tabular}{lcrr}
\hline Phenotypes & $\begin{array}{c}\text { Observed } \\
\text { number }\end{array}$ & $\%$ & Allele frequency \\
\hline $\mathrm{Rh}+\mathrm{ve}$ & 85 & 92.39 & $\begin{array}{r}D=0.9239 \\
\mathrm{Re}\end{array}$ \\
$\mathrm{Rh}-\mathrm{ve}$ & 7 & 7.60 & 0.0760 \\
\hline Total 92 & 100.00 & & 1.0000 \\
\hline
\end{tabular}

$(0.6756)>B(0.2199)$ and $A(0.1155)$. The table also shows the distribution of observed and expected percentage frequencies of $\mathrm{ABO}$ Phenotypes. The population under study is in genetic equilibrium and any observed fluctuations are due to chance alone. In case of Rh (D) blood groups $92.39 \%$ were positive and $7.60 \%$ were negative. The allele frequencies being 0.9239 for $D$ and 0.0760 for $d$ (Table 2).

\section{ACKNOWLEDGMENTS}

The authors are grateful for the financial support given by the UGC, New Delhi, under Special Assistance Programme to the Department of Anthropology, Sri Venkateswara University, Tirupati.

KEY WORDS Blood Groups. Genetic Variation. Fishermen

ABSTRACT In the present study the blood samples of 92 unrelated subjects of the Telugu speaking fishing community of coastal Andhra Pradesh were analysed for $\mathrm{ABO}$ and $\mathrm{Rh}$ (D) blood groups. The overall picture of $\mathrm{ABO}$ percentage is $\mathrm{O}(45.65 \%)>\mathrm{B}(32.60 \%)>\mathrm{A}(15.21 \%)>\mathrm{AB}(6.52 \%)$. The frequency of $\mathrm{Rh}+\mathrm{ve}(92.39 \%)$ is more than $\mathrm{Rh}-\mathrm{ve}(7.60 \%)$.

\section{REFERENCES}

Bhasin, M.K., Walter, H. and Danker-Hopfe, H.: The Distribution of Genetical Morphological and Behavioural Traits Among the Peoples of Indian Region. Kamla-Raj Enterprises, New Delhi (1992).

Bhasin, M.K., Walter, H. and Danker-Hopfe, H. People of India: An Investigation of Biological Variability in Ecological, Ethno-economic and Linguistic Groups. Kamla-Raj Enterprises, New Delhi (1994).

Mourant, A.E., Kopec, A.D.A. and Domanieswska-Sobezek, K.: The ABO Blood Groups- Comprehensive Tables and Maps of World Distribution. Blackwell Scientific Publication, Oxoford (1976).

Race, R.R. and Sanger, R.: Blood Groups in Man. IV Ed. Blackwells, Oxoford (1962). 
Authors'Address: A. Papa Rao, K.K. Reddy and N.S. Balaji Rao, Department of Anthropology, Sri Venkateswara University, Tirupati 517 502, Andhra Pradesh, India 